\title{
ALEXANDRE: LUGARES COMUNS, PERSONAGEM INCOMUM
}

Jacyntho Lins Brandão*

Recebido em: 06/03/2020

Aprovado em: 22/03/2020
* Professor Emérito, Faculdade de Letras, Universidade Federal de Minas Gerais. linsbrandao@gmail.com

RESUMO: Este trabalho pretende oferecer uma visão geral de tradições relativas a Alexandre Magno, do ponto de vista do papel que nelas tem o uso de alguns lugares comuns aplicados a sua figura. O relato do PseudoCalístenes (recensão $\beta$ ) em Vida de Alexandre serve como ponto de partida para a análise de algumas tradições concernentes à natureza excepcional de Alexandre e sua apresentação como um rei culto e sábio.

PALAVRAS-CHAVE: Alexandre Magno; Pseudo-Calístenes; Romance de Alexandre; lugares comuns.

\section{ALEXANDER THE GREAT: \\ COMMONPLACES, UNCOMMON CHARACTER}

\begin{abstract}
This paper aims to offer an overview of some traditions related to Alexander the Great, discussing the role of some common places applied to the figure of the king. Callisthenes' account in the Life of Alexander (recensio $\beta$ ) serves as a starting point for analyzing some traditions relating to Alexander's exceptional nature and his presentation as a learned and wise man.
\end{abstract}

KEYWORDS: Alexander the Great; Pseudo-Callisthenes; Alexander Romance; commonplaces.

Para Pedro Ipiranga Júnior

N

o romance de Ismail Kadaré intitulado A filha de Agamêmnon \& O sucessor, composto por um díptico cuja primeira parte foi escrita em 1985, na Albânia, durante a ditadura, e a segunda em 2002-2003, quando o livro foi publicado na França, 
conta-se o dilema de um arquiteto que sabe um terrível segredo capaz de elucidar um assassinato - a existência de uma porta secreta na casa do morto, por onde poderia ter passado o assassino -, mas sua esposa o faz jurar não falar jamais nisso, sequer "em lugares desertos, onde não exista vivalma", lembrando-lhe a história do barbeiro do fidalgo, a qual ela "pôs-se a contar [...] em voz baixa, à maneira de quem entoa uma canção de ninar":

Ele [o Arquiteto], com os olhos semicerrados, imaginava a planície deserta por onde vagara aluado o barbeiro, ao deixar a casa do fidalgo. O segredo que descobrira ao cortar os cabelos do cavaleiro era de um horror desmedido. E igualmente pavorosa fora a ameaça do senhor. Se contares a quem quer que seja o que viste em mim, pobre de ti, homem! Mas o barbeiro, à lembrança dos dois pequenos cornos na parte de baixo do crânio do freguês, sentia que o que vira era de tal monta que não conseguiria guardar consigo. Por isso, procurara em meio à desolada planície hibernal um lugar ainda mais ermo, onde pudesse dizê-lo em voz alta. Assim, chegara à beira de um poço abandonado, ao lado de uns caniços que o vento agitava, e ali, debruçado sobre o poço, dissera:

O que sei

Sabe ninguém

Gjork Golem

Chifres tem.

Mais tranquilo, seguira então para seu povoado, certo de que, agora que arrancara de si o segredo, este não mais o atormentaria, fosse na taverna, fosse em casa. Mas pouco mais tarde, um pastor, que passava pelo poço, parara e cortara um caniço, para dele fazer uma flauta. Talhara-a num instante, como sabem fazer os pastores, abrira-lhe sete furos e levara-a aos lábios para tocar, mas, para seu espanto, em vez da familiar melodia tinham soado as palavras:

O que sei

Sabe ninguém

Gjork Golem

Chifres tem. (Kadaré, 2006, p. 125-7)

Cito essa história com múltiplas intenções. A primeira delas, a mera constatação de como um enredo procedente da Antiguidade pode continuar ativo, no caso em tela, na tradição albanesa, o que o mero fato de constar de uma obra contemporânea, publicada no século XXI, garante. O primeiro registro de que dispomos da história envolvendo um barbeiro, o segredo contado num buraco e os caniços que o repetem, está nas Metamorfoses de Ovídio, com referência ao comportamento do rei Midas, quando de uma disputa musical entre Pã e Apolo. Segundo o poema, 
Pã faz soar sua rústica flauta e, com seu rude canto, encanta Midas, ocasionalmente presente junto a si. A seguir, o sagrado Tmolo volta sua face para a face de Febo. $[\ldots]$ Sua pose era de artista. Com seu hábil polegar, faz então vibrar as cordas. Fascinado com aquela suavidade, o Tmolo convida Pã a submeter a cana à cítara.

Todos concordaram com o juízo e a sentença do divino monte. Só Midas os contesta e os considera injustos. Não suporta Délio que aquelas fátuas orelhas mantenham a forma humana. Alonga-as e cobre-as de pele esbranquiçada, torna-as flexíveis na base e faz que possam mover-se. O resto mantém-se humano. Só nesta parte punido, assume orelhas de ronceiro burro. Ao querer escondê-las, Midas tenta, com grande pejo, cobrir as têmporas com um capuz vermelho. Mas, habituado a cortar-lhe os cabelos, quando crescidos, com uma lâmina, o servo tinha visto tudo. Ansioso por difundir tal fato, não ousando, embora, revelar a desonra vista, sem poder, também, guardar silêncio, afasta-se, abre na terra uma cova e, em voz baixa, num murmúrio, relata à terra escavada que tipo de orelhas vira a seu senhor. Com a terra tirada, cobre o som da sua voz e, tapado o buraco, parte em silêncio. Espesso tufo de trêmulas canas começa a brotar ali e, logo que, passado um ano, atinge a maturação, atraiçoa aquele que as semeou. De fato, agitado por um suave Austro, repete a palavra ouvida e denuncia as orelhas de seu senhor. ${ }^{1}$

${ }^{1}$ Cf. Metamorfoses, 11, 157-93 (trad. Domingos Lucas Dias, a partir da edição de R. J. Tarrant): "Monte suo senior iudex consedit et aures/ liberat arboribus: quercu coma caerula tantum/ cingitur, et pendent circum cava tempora glandes./ isque deum pecoris spectans 'in iudice' dixit/ 'nulla mora est.' calamis agrestibus insonat ille/ barbaricoque Midan (aderat nam forte canenti)/ carmine delenit; post hunc sacer ora retorsit/ Tmolus ad os Phoebi: uultum sua silua secuta est./ ille caput flauum lauro Parnaside uinctus/ uerrit humum Tyrio saturata murice palla/ distinctamque fidem gemmis et dentibus Indis/ sustinet a laeua, tenuit manus altera plectrum;/ artificis status ipse fuit. tum stamina docto/ pollice sollicitat, quorum dulcedine captus/ Pana iubet Tmolus citharae submittere cannas./ Iudicium sanctique placet sententia montis/ omnibus, arguitur tamen atque iniusta uocatur/ unius sermone Midae. nec Delius aures/ humanam stolidas patitur retinere figuram,/ sed trahit in spatium uillisque albentibus implet/ instabilesque imas facit et dat posse moueri./ cetera sunt hominis; partem damnatur in unam/ induiturque aures lente gradientis aselli./ [ille quidem celare cupit turpique pudore]/ tempora purpureis temptat relevare tiaris;/ sed solitus longos ferro resecare capillos/ uiderat hoc famulus, qui cum nec prodere uisum/ dedecus auderet; cupiens efferre sub auras, / nec 
Que Midas tenha adquirido orelhas de asno no mesmo contexto testemunha também Higino ("tal coração tendo para julgar, tais orelhas também tenhas", diz-lhe Apolo), ${ }^{2}$ sem que, contudo, se faça menção à ação do barbeiro, um entrecho que se repete, por exemplo, no chamado Romance de Tristão, de Béroul (séc. XII), em que, em nova variante, sem que se diga por que o rei Marcos, da Cornualha, tem orelhas de cavalo, o segredo é contado pelo anão que o conhece a uma fossa e ouvido pelos três barões que são os vilões da história. ${ }^{3}$

Não são só as ocorrências, mas são sobretudo as diferenças entre diversas versões que conferem a esse entrecho o estatuto de "lugar comum". Isso constitui a segunda razão por ter eu aberto esta fala citando o romance de Ismail Kadaré: permitir-me esclarecer o que nomeio com essa expressão. Não tomo "lugar comum" de uma perspectiva depreciativa, como se fez muitas vezes, dos alexandrinos aos românticos, como se nomeasse nada mais que um contraposto sem valor da "originalidade". Entendo, pelo contrário, que lugares comuns são aquilo que permite a uma cultura constituir-se enquanto tal, na qualidade de tópoi de circulação generalizada, que podem ser de todos porque de ninguém em particular, ou seja, tomo-os na condição de elementos de inteligibilidade que, na trama da cultura, por serem comuns, permitem a comunicação e o sentimento de pertença a uma mesma comunidade. Quando eles se perdem, esvai-se a possibilidade de comunicar-se e comunizar-se (se me é permitido o neologismo), os ruídos sobrepondo-se ao discurso.

Recordemos que "lugares comuns" (koinoi tópoi/ loci communes), como uma categoria discursiva, é um modo de dizer que remonta à Antiguidade grega. O primeiro registro da palavra tópos aplicado a um discurso encontra-se no Elogio de Helena de Isócrates, nomeando tanto formas de argumento erístico (seja como fato ou possibilidade, o que Aristóteles chamará de tà koiná), quanto o testemunho dos antigos, no caso em pauta, especificamente à opinião de Teseu sobre Helena (Elogio de Helena 4 e 38 respectivamente). Tanto na Retórica, quanto nos Tópicos, Aristóteles usa o conceito de lugares comuns (koinoi tópoi), fornecendo uma lista de vinte e oito a partir dos quais se podem formar entimemas (além do tópos do

posset reticere tamen, secedit humumque/ effodit et domini quales aspexerit aures, / uoce refert parua terraeque immurmurat haustae; indiciumque suae uocis tellure regesta/ obruit et scrobibus tacitus discedit opertis./ creber harundinibus tremulis ibi surgere lucus / coepit et, ut primum pleno maturuit anno,/ prodidit agricolam; leni nam motus ab Austro/ obruta uerba refert dominique coarguit aures." Salvo indicação em contrário, todos os textos gregos e latinos são citados na edição da coleção Budé. ${ }^{2}$ Higino, 191: Midas rex Mygdonius filius Matris deae a Timolo arbiter sumptus eo tempore, quo Apollo cum Marsya vel Pane fistula certavit. Quod cum Timolus victoriam Apollini daret, Midas dixit Marsyae potius dandam. Tunc Apollo indignatus Midae dixit: "Quale cor in iudicando habuisti, tales et auriculas habebis." Quibus auditis effecit, ut asininas haberet aures.

${ }^{3}$ Béroul, 1315-34: "Para guardar segredo seu/ Sempre me teve por fiel./ Isso quereis, bem sei, ouvir,/ Mas não me quero desmentir./ Os três de vós levar-vos ouso/ Até ao Vau Aventuroso./ Existe lá branco espinheiro,/ Sob a raiz, um fosso inteiro:/ Dentro a cabeça vou botar,/ De fora me ouvireis falar:/ Segredo é, pois, o que direi,/ Isso confiou a mim o rei./ Os barões vêm ao espinheiro,/ Frocine na frente, primeiro./ Baixo era o anão, cabeça grande,/ Por isso assim o fosso expande/ E até as espáduas nele o põem:/ Ora escutai, nobres barões!/ Arbusto, a vós, não a vassalo:/ Tem Marco orelhas de cavalo.” (trad. Jacyntho Lins Brandão, 2020, p. 134-7). 
mais e do menos, o da oposição, o da correlação, o da volta do dito contra quem disse, o da definição, o da divisão, o da indução, o da implausibilidade etc., Retórica 1397a-1401a). Conforme Grimaldi, “a partir do que diz Aristóteles, esses tópoi são princípios axiomáticos que oferecem ao rétor variados caminhos para fazer inferências, por enthýmema ou parádeigma, em qualquer assunto" (Grimaldi, 1980, p. 356). De acordo com os rétores gregos e latinos, a função do lugar comum num discurso é sobretudo a da amplificação, ou seja, justamente por sua capacidade de generalização pode ele reforçar o argumento que trata do particular. Em resumo, nos termos de Lausberg, "o locus communis é um pensamento infinito que é aplicado, como argumento ou ornamento, ao tratar-se uma quaestio finita" (Lausberg, 1993, p. 236).

A teologia definiu como loci communes as dez principais fontes de provas da fé, a saber: a escritura, a tradição, a autoridade da Igreja, as decisões dos concílios, a autoridade dos pontífices romanos, os padres da Igreja, os filósofos, os jurisconsultos, os historiadores e a razão natural. O que interessa sobretudo nessa configuração é o peso que nela adquire a tradição - o que já se encontrava em Isócrates, com relação à opinião de Teseu sobre Helena -, ou seja, o lugar comum deixa de restringir-se às proposições de caráter geral e validade universal (o que na lista se nomeia como a "razão natural"), para buscar sua principal autoridade no acúmulo de opiniões. Essa configuração está na base do conceito moderno de lugar comum no sentido do "pré-construído", do "universo de referência" de que pode servir-se o escritor (Quet, 1978, p. 57), o que a retórica grecolatina classifica de preferência sob a rubrica de paradeígmata/ exempla, os quais abrangem "anedotas históricas, sentenças e adágios, fábulas, oráculos e mesmo comparações", recolhidos em obras "que o escritor pode consultar sem reportar-se às fontes primeiras" (Bompaire, 2000, p. 380-1).

Entendendo-se assim o "lugar comum" e justificando-se que se aplique tal conceito à história do barbeiro inconfidente, convém notar uma diferença na versão albanesa com relação à de Ovídio: havendo o segredo, o barbeiro e os caniços que o divulgam, não estão em causa orelhas de asno, mas "dois pequenos cornos na parte de baixo do crânio" do fidalgo - o que nos conduz à outra função que atribuo ao entrecho: a de prover-lhe uma situação, mais exatamente, um lugar. Conforme Michael Wood, no livro, publicado em 2001, com o título de Nas pegadas de Alexandre, o Grande, em que ele afirma ter feito o percurso do rei macedônio em suas campanhas pelo Oriente, a seguinte história é contada "por toda parte, da Turquia ao Cazaquistão", envolvendo Iskander - que é a forma local do nome de Alexandre:

Iskander era realmente um demônio e tinha chifres. Mas seu cabelo era longo e ondulado e os chifres nunca eram vistos. Somente seus barbeiros sabiam. Mas ele temia que eles não pudessem guardar o segredo. Assim, matava-os quando o descobriam. Seu último barbeiro fingiu não notar e guardou o segredo. Então, como não podia suportar isso mais tempo e como não podia contar para ninguém, correu a um poço e disse para dentro do poço: Iskander tem chifres! Mas no fundo do poço havia caniços e eles ecoaram a história, até que ela deu volta ao mundo inteiro. (Wood, 2001 [1997]) 
Essa tradição oral ainda em curso na Ásia central - a de que Alexandre tinha chifres - parece de fato bastante difundida. Segundo Doufikar-Aerts, há uma expressão usada por crianças, no nordeste da Anatólia, quando convencionam guardar entre si um segredo: perguntando a primeira "Zülkenderin boynuzu var?" - que significa "Zülkender (isto é, Alexandre) chifres tem?" - a outra deve responder: "boynuzu var" - "chifres tem". Em versões da história na mesma região, Iskander/Zülkender ocultava os chifres usando um turbante (ou seja, como Midas escondia as orelhas de cavalo), o barbeiro conhecendo o segredo etc. (cf. Doufikar-Aerts, 2012, p. 70). O fato de que Alexandre, com o nome Dhu'qarnayn (dois cornos), esteja numa sura do Quran (18, 83-98), prova o quanto essa tradição se prolonga no Oriente, neste caso a explicação para os dois chifres sendo dada pelo fato de que o rei havia atingido tanto o lugar onde o sol nasce, quanto onde se põe (cf. Zuwiyya, 2011, p. 74-5).

A tradição dos chifres de Alexandre aparece apenas alusivamente nas fontes literárias, mas tem uma pequena mas expressiva documentação iconográfica, procedente da época helenística, de que um exemplo é este tetrádracma mandado cunhar por Lisímaco, rei da Ásia Menor, da Trácia e da Macedônia a partir de 306 a.C. - antigo general, guarda-costas e um dos diádocos de Alexandre -, a moeda sendo, portanto, de entre 306 e 281 a.C., ano da morte de Lisímaco:

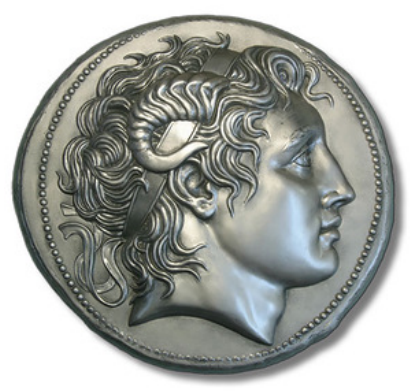

Embora o modelo iconográfico seja relativamente comum - os cabelos revoltos, o chifre e o diadema que passa sob o chifre -, é muito raro em escultura, o único exemplar conhecido sendo um mármore, procedente de Cartago ou Utica, na Tunísia (hoje no Nationalmuseet de Copenhagen), datado entre 250-300 d.C., cópia romana de um modelo mais antigo, em que se veem os dois chifres de carneiro laterais e, no centro, o local onde seriam encaixadas duas presas e a tromba de um elefante, traços que também integram a iconografia médio-asiática de Alexandre (cf. Fulinska, 2012, p. 393-4).

$\mathrm{Na}$ documentação literária, a informação mais direta sobre esse tema procede de Efipo Olíntio, que, acredita-se, se não foi contemporâneo de Alexandre, viveu em época próxima dele - alguns defendendo que se pudesse tratar do Efipo de Calcídia, que, conforme Arriano, foi deixado pelo rei como epískopos no Egito. Seja ele quem for, Ateneu informa que 
Efipo diz que Alexandre envergava vestimentas sagradas nos banquetes: às vezes, de Amon, as vestes de púrpura, os calçados e chifres, como o deus; às vezes, também a de Ártemis, a qual sobre a armadura punha muitas vezes, tendo a stilé persa, mostrando sobre os ombros o arco e a lança; algumas vezes também como Hermes [...]; e muitas vezes ainda a pele de leão e a clava, como Héracles.

(Efipo Olíntio, fr. 3)

Assim, a representação de Alexandre com chifres poderia provir do travestismo do próprio rei como Amon - ou mesmo como Zeus-Amon, já que o resultado da conflução do deus grego com o líbio implicava justamente na imposição ao primeiro dos chifres de carneiro próprios do segundo.

A par do travestismo, toda efabulação relativa à filiação divina de Alexandre também justificaria tal representação. Conforme Plutarco, essa crença teve origem num mal-entendido, quando da visita do rei ao oráculo de Amon, na Líbia, uma vez que,

depois que Alexandre cruzou o deserto e chegou a seu destino, o profeta de Amon saudou-o da parte do deus como se ele fosse seu filho. [...] Sustentam alguns que o profeta, querendo saudá-lo em grego com uma palavra afetuosa, chamou-o ô paidion! (ó filhinho!), mas, em sua pronúncia bárbara, substituiu o $-n$ final por um $-s: \hat{o} p a \hat{\imath}$ Diós! (ó filho de Zeus!). Acrescentam que Alexandre folgou muito com esse lapso, espalhando-se então o boato de que o deus o chamara efetivamente de "filho de Zeus".

(Vidas paralelas, Alexandre 27, trad. Cardoso)

Parece que Alexandre tirava proveito da crença de que era filho de um deus - Zeus ou Amon, ou, mais exatamente, Zeus-Amon -, embora agindo de modo diverso em cada situação: é ainda Plutarco quem conta que ele "costumava ser altivo com os bárbaros e dava-lhes a impressão de estar absolutamente convicto de sua filiação divina", sendo, com os gregos, "mais moderado e discreto". Consta, inclusive, que, certa vez, "ferido por uma flecha e padecendo dores cruciantes, afirmou”, usando de um verso de Homero: “O que corre aqui, amigos, é sangue e não 'o ícor que flui pelas veias dos deuses venerandos"' (Plutarco, Vidas paralelas, Alexandre 28; cf. Homero, Iliada 5, 340).

Ser julgado filho de um deus constitui um dos lugares comuns típicos na biografia de heróis da zona de convergência cultural do Mediterrâneo oriental - desde Gilgámesh, que era dois terços divino e um terço humano, sua mãe sendo uma deusa, a vaca selvagem Nínsun, até Aquiles, Eneias, Sarpédon e tantos outros da tradição grega e romana. O caso de Alexandre é análogo ao de Héracles - de quem, conforme Plutarco, ele descendia (Vidas paralelas, Alexandre 2) -, por contarem ambos com um pai humano, Filipe e Anfitrião, respectivamente, ora considerados não mais que putativos, ora tidos como verdadeiros, o que faz com que a filiação divina permaneça indecidida. 
É na Vida de Alexandre do Pseudo-Calístenes, do século V d.C., ${ }^{4}$ a qual recolhe tradições anteriores, que essa temática ganha maior expansão e complexidade. Esse chamado "romance" tem especial importância por ter sido, sem dúvida, a origem e o principal difusor da "matéria de Alexandre" no Oriente e no Ocidente, a qual se registra da Islândia à China e da Rússia à Etiópia, dando origem mesmo a tradições antagônicas: para o Zoroastrismo do Irã, Alexandre era um cruel destruidor, seu nome, no Iraque, sendo ainda sinônimo de bicho-papão, enquanto na literatura persa ele é apresentado como um rei legítimo, sábio governante e explorador piedoso, os romances árabes dando-lhe o perfil de um profeta de Deus (o Dhu'l-qarnayn, 'dois cornos'), do mesmo modo que nas literaturas europeias ele se apresenta como rei sábio e cristão, semelhante a Cristo e protetor da Cristandade (cf. Stoneman, 2012, passim; Zuwiyya, 2011, passim).

Parece que, na narrativa do Pseudo-Calístenes, o que se pretende é justificar que o herói ocupara legitimamente o trono dos faraós, de modo que, na disputa relativa à filiação, o autor atribui-lhe não dois pais - Filipe e Amon -, mas três - Filipe, Amon e Nectanebo. Este foi o último faraó do Egito, perito em artes mágicas, o qual, diante da iminente derrota para os persas, fugiu para Pela, capital da Macedônia, e seduziu Olímpia, esposa do rei Filipe. Como a rainha estivesse temerosa diante de uma profecia segundo a qual seu marido, Filipe, a desprezaria e se casaria com outra, Nectanebo lhe garante que "é preciso que você se una a um deus sobre a terra, que engravide dele, que dê à luz o seu filho e que o crie", esse deus sendo "Amon, da Líbia" (Pseudo-Calístenes 4). Depois de fazer a rainha sonhar com o deus, a fim de que o reconhecesse,

Nectanebo trajou um velo de lã de carneiro delicadíssimo, com dois chifres nas têmporas, estes com aparência de ouro, um cetro de ébano, uma túnica branca e um manto translúcido com aparência de serpente. Entrou no quarto, e ali sobre a cama estava Olímpia, coberta. Ela o olhava com o canto dos olhos: ao vê-lo entrar, não teve medo, porque ele se parecia com o que tinha ela visto em sonho. Nectanebo se livrou do cetro, deitou na cama e se uniu a ela. E disse-lhe: Conserve-se, mulher! Você tem no seu ventre um menino que será seu vingador, rei de todo o mundo habitado e senhor do universo! (Pseudo-Calístenes 7, trad. Rabelo)

Assim, tanto Filipe, quanto Amon não passariam de pais putativos de Alexandre, o verdadeiro sendo Nectanebo, o qual, contudo, só o é em vista de seu disfarce - a tradição de que o próprio Alexandre costumava vestir-se com os chifres de Amon coincidindo com esse travestismo de origem. Ora, é essa origem incomum que justifica outros traços também fora do comum: embora não haja no Pseudo-Calístenes nenhuma alusão a chifres, assevera ele que "Alexandre não se parecia nem com Filipe, nem com sua mãe, Olímpia, nem com aquele que o engendrou", mas, com "uma fisionomia própria, tinha forma humana, cabeleira

\footnotetext{
${ }^{4}$ Os textos das recensões $\beta$ e $\gamma$ são datados entre os séculos V e VII d.C., enquanto a datação da recensão $\alpha$, segundo a maior parte dos especialistas, situa-se por volta do século III d.C.
} 
de leão, e os olhos eram de tons diferentes - tinha o direito escuro e o esquerdo claro", bem como "os dentes eram afiados como as pontas dos das serpentes, e o seu ânimo se revelava como o do leão, era agudo e notório.” Mesmo que se trate de traços incomuns, representam uma reunião de lugares comuns heroicos, como os olhos de duas cores, atributo também do poeta mítico arcaico Tâmiris, referido na Ilíada por ter desafiado as Musas e tido por filho de uma ninfa ou mesmo de uma das Musas. Os lugares comuns repetem-se por ocasião do nascimento de Alexandre, envolvendo prodígios cósmicos: "Olímpia deu um mugido alto como o de uma vaca e pariu um menino dotado de boa sorte. Quando o menino parido desceu sobre a terra, vieram os trovões ribombando sucessivamente e a luz dos raios, como se todo o universo se agitasse" (Pseudo-Calístenes, 13).

$\mathrm{Na}$ impossibilidade de, aqui, resenhar todos os lugares comuns que se observam na vida de Alexandre, desejo deter-me num dos mais significativos, que se aplica à morte de seu pai, Nectanebo, quando o jovem príncipe tinha doze anos. Além do interesse de observar o percurso de um entrecho narrativo cujo ponto de chegada antigo é a vida de Alexandre, ele nos permitirá temporalizar nossa consideração de como se lança mão dos lugares comuns aplicados a personagens sempre incomuns -, confirmando-os em sua função de comunicação e ressignificando-os. Segundo o Pseudo-Calístenes,

dispondo sua tabuinha e as estrelas, [Nectanebo] põe-se a investigar sobre a rainha, enquanto Alexandre estava junto deles. E Alexandre diz-lhe: - Profeta, não aparecem no céu esses astros de que você fala? - Claro que aparecem, filho! disse ele. E diz-lhe Alexandre: - Não consigo vê-los. E ele disse: - Sim, filho, você conseguirá quando ficar de noite. E de noite Nectanebo toma Alexandre e o conduz fora da cidade, a um lugar ermo e, olhando para o céu, mostrava a Alexandre as estrelas celestes. Alexandre, agarrando-lhe a mão, leva-o até um buraco e solta-o lá dentro. Ao cair, Nectanebo sofreu um terrível golpe na nuca e lhe disse: - Ai de mim, meu filho Alexandre, por que você resolveu fazer isso? E disse Alexandre: - Critique a você mesmo, astrólogo [mathematiké]! E ele falou: - Por quê, filho? Diz Alexandre: - Porque, não sabendo o que há na terra, você investiga o que há no céu. ${ }^{5}$

Esse episódio remete o leitor à fábula de Esopo intitulada Um astrólogo, em que também se encontram presentes o sábio que investiga os astros, o poço e uma personagem anônima:

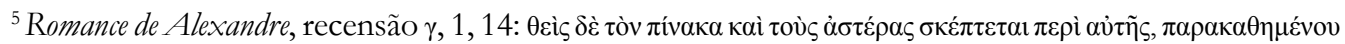

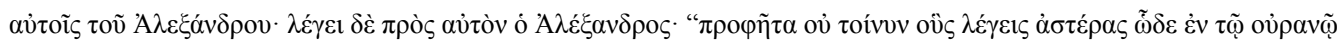

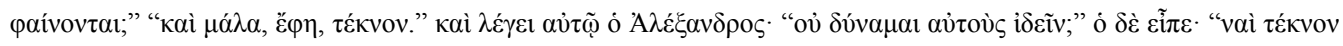

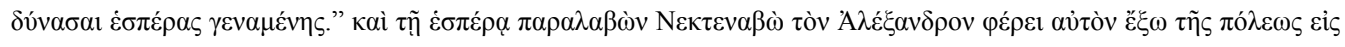

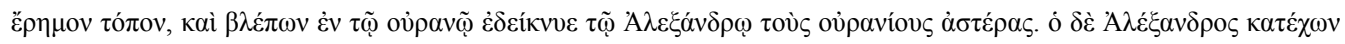

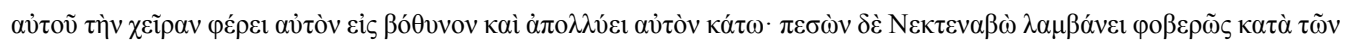

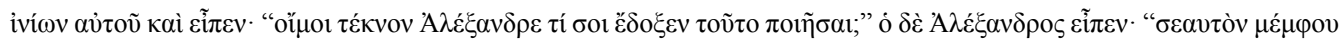

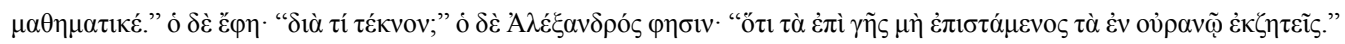


Um astrólogo, saindo cada noite, tinha o costume de observar as estrelas. Então, certa vez, perambulando pelo subúrbio e tendo toda a atenção posta no céu, caiu sem perceber num poço. Como ele se lamentasse e gritasse, alguém que passava perto, ouvindo os gemidos, aproximou-se e, sabendo o que tinha acontecido, disse-lhe: - Ei você! tentando ver o que há no céu, o que há na terra você não vê?6

O mesmo entrecho, na linha do que faz o autor da Vida de Alexandre, recebe uma formulação mais precisa da parte de Platão, na qual o astrólogo/astrônomo é identificado com Tales de Mileto, conforme se lê no Teeteto:

Como Tales observasse os astros [astronomoûnta] [...] e olhasse para o alto, tendo caído num poço, uma trácia, serva arguta e gracejadora [emmelès kai khariesa], se diz que dele zombou por cuidar de saber o que há no céu, esquecendo o que estava diante de si, a seus pés. ${ }^{7}$

Como já ressaltei em outros trabalhos, é difícil saber se Platão depende de Esopo ou vice-versa, em vista da incerteza em datar as fábulas atribuídas ao segundo, mas supor que Platão remeta à fábula nada tem de absurdo, pois, de um lado, ele próprio informa que Sócrates conhecia os "mitos" de Esopo (cf. Fédon 61b) e, de outro, a identificação do astrólogo da fábula com Tales surte mais efeito caso se considere a relação entre os dois textos. Assim, tanto ressalta como, diferentemente do que concerne a Tales, na história de Esopo o astrônomo lamenta, grita e geme, quanto constitui um elemento importante o fato de que a segunda personagem, sem traços da fábula, se apresente em Platão como uma mulher, trácia, serva, arguta e gracejadora. Isso faz com que a moral das duas histórias também divirja, num caso dirigindo-se contra os contadores de prodígios (hoi paradóxos alazoneúontai), no outro, a "todos que passam o tempo na filosofia", pois, "na verdade, passa despercebido para este [o filósofo] tanto quem está a seu lado, quanto quem é seu vizinho, não sabendo ele não só o que eles fazem, mas, por pouco, também se são homens ou algum outro animal". Nos dois casos, os autores lidam com um lugar comum já em curso pelo menos no último quarto do séc. V a.C. - o sábio teórico que não vê o que está a seus pés -, o qual fornece a Aristófanes variadas imagens para caracterizar o próprio Sócrates e seus discípulos, na comédia Nuvens, encenada em 423: Sócrates aparece pendurado numa "cesta" porque, diz ele, "caminho no

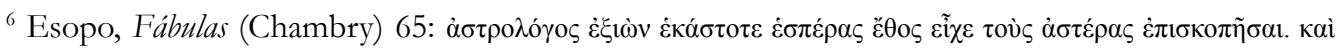

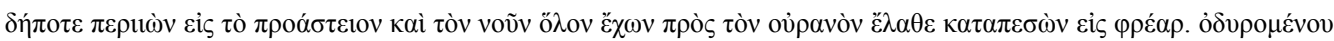

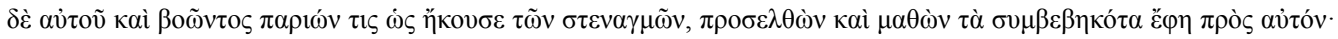

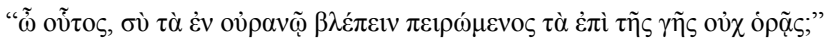

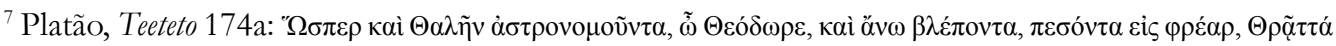

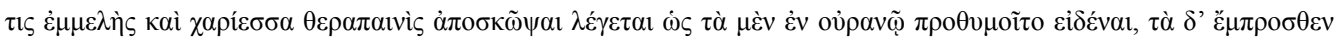

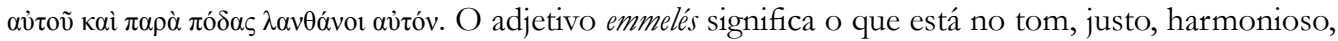
bem proporcionado, comedido, moderado, apropriado, conveniente, de bom gosto; kharieis, gracioso, hábil para fazer alguma coisa (no campo da música, da medicina, da agricultura etc., inclusive no da filosofia, cf. Platão, Cartas 363c).
} 
alto e observo o sol" (aerobatô kaì periphronô tòn hélion, Nuvens 225), e, ao saber como, certa vez, ele arranjara espertamente o que comer, Estrepsíades exclama: "Por que então ficamos admirados com o tal de Tales?” (Nuvens 180). Assim, é como se os elementos para a versão platônica já estivessem dados, bastando-lhe fazer confluir o que há de comum entre Esopo e Aristófanes, que dá nome aos bois: Tales e Sócrates.

O prolongamento dessa tradição além do século IV é testemunhado por Diógenes Laércio, que transmite uma variante da anedota sobre Tales, em que se põe em cena, como segunda personagem, uma velha:

diz-se que, conduzido por uma velha para fora de casa, a fim de que observasse os astros, ele caiu num buraco e, como lamentasse, lhe disse a velha: - Você então, ó Tales, não podendo ver o que está a seus pés julga conhecer o que há no céu? ${ }^{8}$

No universo dos escritores latinos, já Ênio, no fragmento conservado da tragédia de nome Ifigênia, registra o dito, que tudo leva a crer se tornara proverbial, aplicando-o contudo não a um filósofo, mas à astrologia propriamente dita (astrologorum signa in caelo):

quando a Cabra ou o Escorpião se levantam, ou algum outro nome de feras, o que está diante dos pés ninguém olha, perscruta as plagas do céu. ${ }^{9}$

No mesmo contexto de crítica às práticas divinatórias, neste caso pelo exame das entranhas de animais, Cícero cita o verso de Ênio, mas curiosamente o atribui a Demócrito: "Demócrito pois, como físico, esse tipo de gente arrogante, diz de modo frívolo, não sem fineza: o que está diante dos pés ninguém olha, perscruta as plagas do céu". ${ }^{10}$ Note-se como o que nos autores gregos é aplicado, de modo jocoso, contra um astrólogo/astrônomo ou um filósofo, por uma personagem do povo - a serva trácia, a velha ou um passante - agora se põe justamente na boca de um filósofo naturalista. Independentemente do que se pretende em cada caso, é a própria migração do lugar comum da boca de uma personagem para outra o que mais chama a atenção.

Ora, se trazemos à colação o episódio da Vida de Alexandre, alguns dados ressaltam. Em primeiro lugar, que, como nos testemunhos latinos, a crítica se dirige a alguém que pratica a astrologia, o que fica bem claro quando Alexandre trata Nectanebo como mathematikós, de

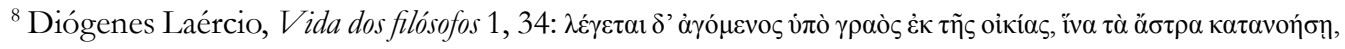

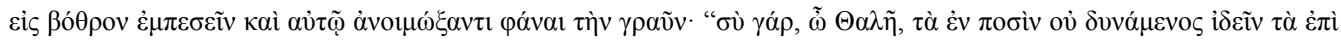

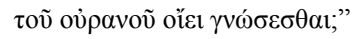

${ }^{9}$ Énio, fr. 95: "cum Capra aut Nepa aut exoritur nomen aliquod beluarum,/ quod est ante pedes nemo spectat, caeli scrutantur plagas".

${ }^{10}$ Cícero, Da adivinhação 2, 13: "Democritus tamen non inscite nugatur, ut physicus, quo genere nihil adrogantius: Quod est ante pedes, nemo spectat, caeli scrutantur plagas. Verum is tamen habitu extorum et colore declarari censet haec dumtaxat: pabuli genus et earum rerum, quas terra procreet, vel ubertatem vel tenuitatem; salubritatem etiam aut pestilentiam extis significari putat". Também em República 1, 30 o verso é citado, com referência à adivinhação pelos astros.
} 
que um sentido corrente, no período pós-clássico, é justamente 'astrólogo', mas pode também ter uma conotação mais genérica, ou seja, alguém que se dedica, em geral, ao estudo, ou às matemáticas em particular, domínio que incluía aritmética, geometria, mecânica e astronomia, o que proveria a conexão com a história de Tales. O elemento mais estranho, entretanto, é que Nectanebo seja conduzido até o buraco e lançado nele por Alexandre, o que parece ter relação com o escárnio à astrologia - pois como alguém que pretende predizer o futuro não preveria esse desenlace? -, mas se encontra já, de um modo mais mitigado, no relato sobre Tales transmitido por Diógenes Laércio, pois, mesmo que a velha não lance o filósofo no buraco, o conduz até ele. É provável que a pretensão de Alexandre fosse mostrar ao adivinho o quanto não podia adivinhar neste caso, embora, com a revelação feita por Nectanebo de que era o seu verdadeiro pai e de que havia uma predição de que morreria pelas mãos do filho, a validade da astrologia afinal se confirme.

$\mathrm{Na}$ direção do futuro, anote-se que esse entrecho do Pseudo-Calístenes serviu de origem a outros. Conforme Manteghi, na obra iraniana Shähnāmeh (Livro dos reis), de Ferdusi (séc. X) - "um livro dos tempos antigos em que há muitas histórias", como o define o próprio autor, no qual Alexandre (Iskandar) aparece como um dos três maiores inimigos do Irã, ao lado de Afrasyiab e Zahhak -, conta-se, a propósito deste último, Zahhak, que, com a ajuda de Satã, levou ele seu pai a um poço no qual o velho caiu e quebrou as costas, morrendo (cf. Manteghi, 2012). Essa história não tem, na obra, nenhuma relação com Alexandre, o que mostra como, enquanto lugar comum, pôde migrar para a biografia de outra personagem, a fonte sendo sem dúvida a Vida de Alexandre do Pseudo-Calístenes (em tradução para o persa ou o árabe), a qual, portanto, assume neste caso a função de relé entre as tradições antigas e as medievais.

É provável que o que diz Alexandre a Nectanebo depois de lançá-lo no poço "Porque, não sabendo o que há na terra, você investiga o que há no céu" - fosse entendido pelo leitor antigo como autêntico provérbio ou citação das cenas envolvendo astrólogos e filósofos. Esse tipo de remissão não é estranho na matéria de Alexandre: por exemplo, ao chegar em casa carregando o cadáver de Nectanebo e ser interrogado pela mãe sobre o que seria aquilo, ele responde: "O jovem Eneias carrega Anquises". Essas mostras de conhecimento e argúcia intelectual são muito destacadas nas biografias de Alexandre, eu diria que mais que as proezas físicas, ou seja, mesmo que as retumbantes vitórias sejam devidas à capacidade estratégica e guerreira do rei, sua singularidade se mostra mais nos entrechos que dão a ver sua sabedoria. Pode-se mesmo dizer que nele confluem as imagens tradicionais de reis sábios da zona de convergência cultural do Mediterrâneo, as quais dele refluem, na sequência, para espaços cada vez mais expandidos.

Examinar alguns dos elementos que apresentam Alexandre como sábio (do que, neste dossiê, se ocupa especialmente Pedro Ipiranga Júnior) permite explorar o cronótopo em que se formam e se expandem os argumentos narrativos que confluem nele e dele defluem. Desejo que não se perca o fio de nosso esforço para lidar de um modo minimamente organizado com esse mar de histórias, motivo por que o recapitulo: começamos com as narrativas do barbeiro, que nos conduziram à compreensão dos lugares comuns; os cornos de Alexandre 
nos proveram um lugar; a queda do sábio no poço permitiu-nos temporalizar um desses lugares prototípicos; agora, a pretensão é considerar tempo e espaço conjugados - por isso falei de cronótopo.

O interesse metodológico dessa última visada está na possibilidade de responder uma questão básica: por que a figura de Alexandre e, em especial, a Vida de Alexandre do Pseudo-Calístenes encontraram uma recepção tão ampla e duradoura a Oriente e Ocidente? Uma resposta imediatista conduziria a pensar que isso dependeu da própria estratégia de comunicação e comunização de Alexandre - em que os lugares comuns tiveram um papel importante: baste recordar que o rei que tinha como livro de cabeceira a Ilíada e demonstra a curiosidade de Ulisses é o mesmo que se veste com a indumentária persa e, tendo uma vez partido, jamais regressou do Oriente. Mas essa seria uma resposta um tanto ingênua, pois o que ponho em causa são as condições de possibilidade para uma recepção tão ampla - dizendo de outro modo: quais lugares comuns tornaram a saga de Alexandre tão incomumente inteligível no tempo e espaço.

Ora, tomando como referência as vidas do herói, o que se constata é que o que elas apresentam é uma narrativa persa: dos setenta e sete parágrafos da vida escrita por Plutarco, por exemplo, apenas os quatorze primeiros se passam na Macedônia e na Grécia, cinquenta e três desenrolando-se nos domínios de Dario, mais a expansão para a Índia, que ocupa dez parágrafos; no Pseudo-Calístenes, só os vinte e oito primeiros parágrafos do livro 1 são gregos, contra cinquenta e oito nos domínios do rei persa e adjacências, nos livros 1 e 2, o terceiro livro sendo dedicado à Índia, ao Egito, às amazonas e outros povos, com o regresso à Pérsia. O que quero dizer é que Alexandre é sim um rei, herói e sábio grego, mas sua saga pode ser tida como o último produto do império persa antigo, a partir de então politicamente incorporado ao mundo grego. Recorde-se que um dos principais ganhos para nosso conhecimento da Antiguidade no século XX foi perceber que os gregos não constituíam uma cultura isolada, mas faziam parte da zona de convergência cultural do Mediterrâneo oriental. Basta lembrar, com base nos relatos gregos, que a Guerra de Troia aconteceu na Ásia, Menelau passou pelo Egito - onde talvez ficara a verdadeira Helena -, isso além dos raptos de asiáticas pelos gregos e de gregas pelos asiáticos, conforme os sábios persas disseram a Heródoto, e assim por diante. Dessa perspectiva, mesmo que com o tempo as relações - nem sempre pacíficas - entre gregos e asiáticos pareçam crescer (como no período orientalizante do século VIII-VII a.C. ou quando das guerras médicas), é só com Alexandre que a citada zona de convergência ganha um contorno político. É como se a Grécia fosse, a Ocidente, a última fronteira a ser politicamente nela incluída, o que foi tentado por Dario I e Xerxes, nas guerras do século V, mas foi logrado apenas por Alexandre, no século seguinte.

Selden define bem o império persa como um "império tributário", ou seja, um espaço em que, da Ásia Menor e do Egito, até a fronteira com a China, os diferentes povos submetidos podiam manter suas línguas, costumes e crenças, obrigando-se apenas a pagar os tributos exigidos pelo Grande Rei (cf. Selden, 2012). Essa forma de organização permite a constituição de extensas comunidades multiculturais, às quais dá amarração uma 
espécie de fidelidade não propriamente econômica, no sentido moderno, mas exatamente tributária, configuração mantida por Alexandre na medida das suas conquistas, praticada também por seus sucessores, bem como adotada, quando se ampliam as fronteiras da zona de convergência a oeste, tanto na Europa, quanto na África, pelo Império Romano (em que, conforme Luciano, todos recebiam um "salário", incluindo o Imperador, o dele sendo as honras). É assim que se entende o desejo dos persas de trazer para seu império não só os gregos da Jônia, como também os da Europa, bem como o fascínio que, sobre os gregos, exerciam os persas, os quais lhes forneciam a imagem do rei justo, Ciro, como descrito por Xenofonte, chegando-se ao ponto de a corte de Xerxes ser transportada para o palco de Atenas e falar grego na tragédia de Ésquilo. São essas trocas anteriores que oferecem, no meu entender, as condições de possibilidade para o sucesso da figura de Alexandre, como se ele fosse, afinal, esperado das duas partes - no sentido do que teria expresso, segundo Flávio Josefo, o sumo-sacerdote quando da chegada do conquistador macedônio em Jerusalém, ao garantir que seu reinado estava previsto nas profecias de Daniel, que prognosticara que um grego havia de conquistar o império dos persas (cf. Antiguidades judaicas 11, 336-45).

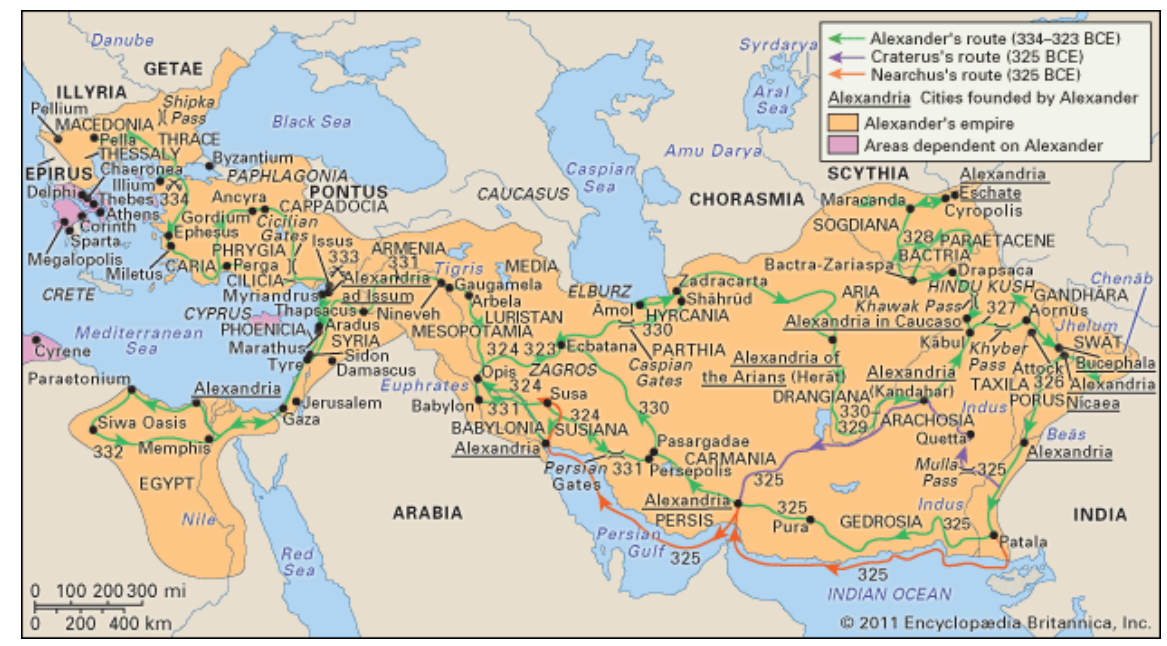

Observando-se o espaço geográfico abrangido pela fugaz conquista de Alexandre, o que se constata é que a Macedônia representa não mais que o extremo noroeste, do mesmo modo que o Egito se encontra no extremo sudoeste, a Paretacena, em cuja ponta se encontra, inclusive, uma das Alexandrias fundadas pelo monarca, sendo o limite a nordeste, enquanto a Gedrósia, mais exatamente a cidade de Patala, marca a fronteira no sudeste. Ora, se imaginarmos linhas transversais que vão de noroeste a sudeste e de sudoeste a nordeste, constataremos que o centro do império de Alexandre não se encontra em nenhum espaço grego, mas no coração do império persa, no círculo em que se situam Nínive, Gaugamela, Arbela, Ecbatana, Opis, Susa e Babilônia. Dessa perspectiva espacial, é significativo que Alexandre tenha partido do extremo noroeste e terminado seu périplo no extremo sudeste - já que a campanha da Índia é a última de suas aventuras -, para morrer no ponto de 
convergência representado pela cidade de Babilônia, que assumiria então o estatuto da casa para onde ele finalmente volta.

Essa qualificação do espaço que a biogeografia de Alexandre nos permite, corresponde a uma temporalidade que, desde que dispomos de documentos escritos, recua até o século XXXIII a.C., quando se cria na Suméria o sistema chamado de cuneiforme e, no Egito, os hieroglifos. A Mesopotâmia tem nesse cronótopo uma importância capital, por sua posição central e pelo fato de seu sistema de escrita ter servido não só aos sumérios, seus inventores, mas ter-se tornado comum também para escrever línguas tão diversas quanto o acádio, o eblaíta, o elamita, o persa, o hurrita, o hitita, o palaíta, o luvita, o urartiano e o ugarítico, circulando, em acádio, também na Síria ocidental, na Palestina e no Egito. Nesse cronótopo contamos com uma documentação literária que remonta ao século XXX a.C., com as chamadas Instruçôes de Shurúppak, texto sapiencial em sumério, atribuído ao último rei antediluviano, no qual se guardam conselhos ancestrais, de acordo com o que se lê na sua abertura: "naqueles dias, naqueles remotos dias,/ naquelas noites, naquelas distantes noites,/ naqueles anos, naqueles remotíssimos anos,/ naquele tempo, o sábio que sabia falar destras palavras vivia na terra:/ Shurúppak..."11 Embora Selden considere que a Vida de Abiqar obra igualmente sapiencial, escrita em aramaico, no Egito, à época da primeira ocupação persa daquele país, ou seja, entre 525-404 a.C. - deva ser considerada o primeiro texto clássico “dos impérios tributários do Mediterrâneo e do Oriente Médio - Irã, Macedônia, Roma, Bizâncio e os califados" árabes -, acredito que seria preciso recuar e considerar a produção suméria e acádia, bastando lembrar a difusão no tempo e no espaço, por exemplo, da matéria de Gilgámesh, desde os primeiros poemas em sumério, no século XXII a.C., até a última tabuinha de que se tem notícia, copiada pela derradeira vez no primeiro século antes de nossa era, o que implica em exatamente dois milênios de circulação de histórias sobre o antigo rei. Mesmo que, a partir do primeiro século d.C., o cuneiforme tenha sido inteiramente abandonado em favor do alfabeto, criado na Palestina por volta do ano 1000 a.C., e, consequentemente, o acádio tenha sido substituído pelo aramaico como língua franca da zona do cronótopo em questão, fazendo com que a saga de Gilgámesh ficasse esquecida (até que as tabuinhas enterradas sob as areias do deserto iraquiano fossem recuperadas, na segunda metade do século XIX), não se pode pensar numa ruptura absoluta, pois, de modos variados, temas, imagens e concepções - dizendo de outro modo: lugares comuns - se transmitem em novas condições.

O tema do rei que viaja até os confins do mundo e, por isso, adquire sabedoria, que é o pivô da versão clássica do poema de Gilgámesh, a que se intitula Ele que o abismo viu (séc. XIII a.C.) deveria, pois, ser tido como um ancestral da representação de Alexandre como rei viajante que adquire uma incomum sabedoria. Com efeito, Gilgámesh é louvado como alguém que

\footnotetext{
${ }^{11}$ Instructions of Shuruppak, 1-5 (disponível em The Electronic Text Corpus of Sumerian Literature, da Universidade de Oxford). Todas as traduções de textos sumérios apresentadas aqui dependem das traduções para o inglês apresentadas nessa base.
} 
o abismo viu, o fundamento da terra,/ seus caminhos conheceu, ele sábio em tudo,/ [...] de todo o saber tudo aprendeu,/ o que é secreto ele viu, e o coberto descobriu,/ trouxe isso e ensinou, o que antes do dilúvio era/ [...] atravessou o mar, o vasto oceano, até onde nasce o sol,/ palmilhou os quatro cantos da terra em busca da vida (v. 3-42).

Trata-se de um programa narrativo que poderia aplicar-se bem a Alexandre - mas, note-se, não a todo e qualquer rei sábio, pois se trata da aquisição de uma experiência de mundo por meio da viagem, modelo em que nem todo rei sábio do mesmo cronótopo se enquadra, por exemplo, Salomão, que é sábio, mas não viajante, sendo justamente a não aplicação indiscriminada do modelo que o torna significativo.

Se é verdade que as viagens de Gilgámesh não têm em vista conquistas, seu reino sendo do início ao fim a cidade-estado de Úruk - um modelo de conquistador podendo ser buscado no rei acádio Sargão -, não se deve também perder de vista que nem todas as incursões de Alexandre visam a conquistas, em especial nos momentos em que extrapolam os limites do mundo, movidas pelo desejo de saber a verdade sobre a terra e o mar. Quero concentrar-me apenas em dois exemplos, aos quais a inclusão na saga de Alexandre deu enorme repercussão, a saber, a descida do rei às profundezas do grande mar e sua subida nos ares (este último recebendo, neste dossiê, uma abordagem detalhada por Ioannis M. Konstantakos). No Pseudo-Calístenes, ambos os episódios são narrados pelo próprio Alexandre, em carta a sua mãe.

No segundo caso, depois de chegar ao que lhe parecia o fim do mundo, "onde o céu se encontra com a terra", Alexandre decide "investigar a verdade", usando do seguinte estratagema:

Mandei capturar duas aves daquele lugar. Eram aves grandes, brancas, muito robustas e dóceis, e que não fugiam quando nos viam. Alguns soldados montaram nos pescoços delas e elas levantaram voo, carregando-os. Comiam cadáveres de bichos, daí que a maioria destas aves vinha até nós pelos nossos cavalos mortos. Depois de capturar duas delas, mandei não dar alimento a elas por três dias. No terceiro dia, mandei fazer um tronco em forma de jugo e amarrar em torno do pescoço delas. Logo preparei a pele de um bovino na forma de um grande cesto e entrei neste cesto carregando duas lanças de sete braças de comprimento, às quais eu tinha prendido fígados de cavalo. De imediato, as aves voaram para devorar o fígado, e eu subi com elas no ar, de forma que acreditei estar perto do céu. Eu tremia todo por causa do ar gelado que subia das asas das aves. Então topou comigo uma figura humana voadora que disse: - Ah, Alexandre! Se você não compreende as coisas da terra, busca as coisas do céu? - e ela falou novamente - Atenção, Alexandre, com a terra aí embaixo! Com cautela, eu olhei e lá havia uma grande serpente em círculo, e no meio da serpente, um círculo menor. A figura humana que se aproximou de mim disse: - Volte a lança em direção ao círculo: aquilo é o mundo. 
A serpente é o mar que circunda a terra. Eu retornei, e por desejo da providência no alto, desci até a terra, a sete dias de distância do acampamento. Ao fim, eu estava agonizante e semimorto. Encontrei um sátrapa do meu domínio e, depois de pegar trezentos cavalos, cheguei ao acampamento. E nunca mais me pus a tentar o impossível.

Essa proeza de Alexandre tornou-se especialmente famosa, tendo sido representada visualmente, tanto em iluminuras, quanto em escultura e tapeçaria. Em La vraye histoire du bon roy Alixandre, manuscrito pertencente à Biblioteca Britânica, do século XIV, o rei apresenta-se numa espécie de gaiola, conduzido por seis grifos, que voam para tentar alcançar o pedaço de carne suspenso numa vara, e Alexandre tem toda a atenção voltada para a terra, pois a finalidade de seu voo é contemplá-la do alto. Em outro caso, há espectadores que, de baixo, assistem ao voo, o que, segundo Schmidt, reproduziria um modelo iconográfico comum nas representações da ascensão de Cristo (para as imagens e comentários, Schmidt, 1995). As iluminuras não são anteriores ao século XII, mas a cena se encontra representada também em esculturas de datas anteriores, um dos exemplares mais famosos sendo o relevo bizantino do século XI que se encontra na fachada da Catedral de São Marcos, em Veneza, em que dois grifos transportam uma espécie de carruagem, onde Alexandre leva duas presas espetadas em varas, olhando para frente e não para baixo. No caso da igreja românica de São Pedro e São Paulo, em Remagen, os elementos iconográficos se mostram mais coerentes com a descrição do Pseudo-Calístenes: o rei é elevado aos ares, numa cesta, por não mais que dois pássaros e tem duas varas nas mãos.

Sabe-se como relatos de viagens aéreas não são incomuns nas fontes gregas e latinas, desde as referências ao voo de Ícaro, que, como no caso do de Alexandre, implica o uso de expedientes tecnológicos. A esse exemplo se podem acrescentar, para ficar nos mais famosos, o voo de Trigeu, conduzido nos ares por um escaravelho, na Paz de Aristófanes, e os que aparecem nas obras de Luciano: Menipo que vai aos ares depois de se ter posto uma asa de águia e outra de abutre, no Icaromenipo, e a viagem aérea do próprio Luciano e seus companheiros em Das narrativas verdadeiras, quando seu navio é lançado para o alto até atingir a lua. Isso nos garante que o tema das viagens aéreas não é estranho ao ambiente greco-romano, mas que não o é também na parte oriental da zona de convergência do Mediterrâneo comprova o poema acádio conhecido como Etana, cuja autoria é atribuída ao sábio Lu-Nanna, que viveu na época de Shulgi, rei de Ur entre 2150 e 2103 a.C., de que se conhecem manuscritos procedentes não só da Mesopotâmia, como também de Susa, capital do império persa: nele, Etana, rei de Kish, dirige-se duas vezes à morada dos deuses Ánu, Ellil e Ea, montado sobre uma águia, para conseguir a planta-do-nascimento, pois não tem filhos. O que aproxima em especial o voo de Etana do de Alexandre é o fato de que ambos sobem conduzidos por pássaros, o que, nos exemplos gregos e romanos, acontece também só no caso de Ganimedes, levado ao Olimpo pela águia de Zeus ou pelo próprio deus metamorfoseado em águia (cf. Teócrito 20, 41; Propércio 2, 30, 30; Ovídio, Metamorfoses 10, 157-161; Luciano, Diálogos dos deuses 4, 1; Myth. Vat. 64, 3-4). Mas o que me parece mais significativo no caso de Etana e Alexandre é o relevo que tem a visão do alto: 
A águia leva-o [a Etana] acima por uma milha:

Amigo meu, olha a terra! Que te parece?

Os negócios da terra zumbem como moscas

E o amplo mar não é maior que um redil.

A águia leva-o uma segunda milha:

Amigo meu, olha a terra! Que te parece?

A terra tornou-se um jardim ----

E o amplo mar não é maior que uma bacia.

Ela leva-o acima uma terceira milha:

Amigo meu, olha a terra! O que te parece?

Estou olhando para a terra, mas não a posso ver,

E meus olhos não podem distinguir o amplo mar!

Amigo meu, não posso ir mais nada em direção ao céu!

Refaz o caminho e leva-me de volta a minha cidade (apudDalley, 2008, p. 198)

Ora, Alexandre lança-se aos ares no interesse de ter esse tipo de visão do alto, o mar lhe aparecendo como uma serpente enrolada a um círculo interno, que era a terra, ou seja, a distância proporciona a visão de algo diminuto mas claramente composto pelo mar envolvendo a terra, como na visão de Etana. Um segundo aspecto comum da experiência de ambos é a constatação do quanto o voo implica em ousadia, pois Etana pede à águia que retorne, tão logo perde a vista da terra, Alexandre sendo repreendido pela "figura humana voadora" que dele se aproxima, dizendo uma variante do lugar comum do sábio teórico: "Ah, Alexandre! Se você não compreende as coisas da terra, busca as coisas do céu?"

Essa repreensão poderia servir de justificativa para a outra aventura extraordinária do rei, a investigação das profundezas do mar. Conforme ainda a carta a Olímpia,

tive a ideia de criar uma grande jaula de ferro, e dentro da jaula colocar um tonel de vidro igualmente grande, com a largura de um braço e meio. Mandei fazer um buraco no fundo do tonel, de forma que houvesse espaço para a mão de uma pessoa. Com a intenção de descer e investigar o que havia no fundo daquele mar, eu fecharia a abertura do buraco no fundo do tonel e desceria até o fundo, abriria o buraco e colocaria a mão para fora, para pegar o que estivesse ao alcance da mão na areia [...], e então de novo bloquearia o buraco rapidamente. Assim foi feito: mandei fazerem uma corrente de 308 braças e estabeleci que ninguém me puxasse para cima até que a corrente sacudisse: - Quando eu chegar ao fundo, vou agitar o meu tonel, daí vocês me levantam. Tudo preparado, entrei no tonel de vidro, querendo tentar o impossível. Estando eu dentro, a saída foi fechada com um apetrecho de chumbo. Ao descer 120 codos, um peixe se aproximou e com sua cauda bateu na jaula e me subiram porque a corrente sacudiu. Desci de novo e o mesmo aconteceu. Ao descer, pela terceira vez, cerca de 308 codos, vi peixes de muitos tipos nadando ao meu redor. E vejo que um peixe gigante se aproximou e me agarrou com a boca, com jaula e tudo mais, e me 
levou para a terra, a uma milha de distância. Os 360 homens que me baixaram estavam em barcos, e ele puxou a todos, junto com quatro barquinhos. Ao atingir a terra seca, o peixe esmagou a jaula com os dentes e me lançou sobre a terra. Eu fiquei meio morto, mortificado de medo. Caído de joelhos reverenciei a providência no alto, que me manteve vivo diante daquele bicho assustador. Falei para mim mesmo: - Abra mão, Alexandre, de tocar as coisas impossíveis, para que você não seja privado da vida, fazendo buscas nas profundezas.

O antecedente de uma aventura desse tipo pode estar na tradição de que Gilgámesh desceu ao Apsû, o abismo de água doce sob a terra, donde procedem fontes e rios, bem como na história hebraica de Jonas, já que Alexandre se viu dentro da boca de um peixe gigantesco que o conduziu até a terra. Mas a exploração mais acabada desse motivo se encontra em Das narrativas verdadeiras de Luciano, em que ele e sua tripulação são devorados por uma enorme baleia, no interior da qual há muitos habitantes, logrando escapar só muito tempo depois. No caso de Luciano e de Jonas, contudo, não há menção à fabricação de algum tipo de veículo submarino, como na Vida de Alexandre, o que sugere a relação com outro relato aparentemente desconexo, o do dilúvio, nas fontes acádias - Atrahasis (Supersábio) e Ele que o abismo viu -, pois a arca construída para enfrentar o cataclisma, conforme as instruções do deus Ea, era coberta, como o Apsu, de modo que o Sol não podia ver dentro dela, tendo compartimentos superiores e inferiores, todas as partes e equipamentos muito resistentes (cf. Ele que o abismo viu 11, 29-31; Atrahasis 3, 1, 25-31), o que leva Andrew George a considerar que se trata de uma “espécie de submarino" (George, 2003, p. 510), permitindo entender por que o Supersábio/Utanapíshti, cada qual em cada um dos dois poemas, pode justificar a construção da arca com uma viagem e estada sob as águas: "Descerei ao Apsu: com Ea, meu senhor, habitarei” (Ele que o abismo viu 11, 42; Atrahasis 3, 1, 47-49).

O último aspecto para o qual desejo chamar a atenção é a relação desses experimentos com a filosofia. Um escoliasta medieval já havia proposto que a origem da cena no interior da baleia, em Luciano, estaria na imagem da caverna de Platão. Todo esse tipo de experiência mental responde, de fato, a uma prática filosófica de percepção do mundo de ângulos inusitados, integrando o rol das experiências mentais capazes de proporcionar distanciamento espacial e temporal, para pôr em questão uma apreensão ingênua da realidade.

É bastante difundida a informação de que Filipe contratou Aristóteles para a instrução de Alexandre, com o que concordam todos os autores, tanto historiadores, quanto biógrafos e ficcionistas. Segundo Plutarco, como Filipe "não se fiasse completamente dos mestres encarregados da instrução" do filho, que era "inflexível e avesso à coação, mas se deixava levar facilmente ao cumprimento do dever quando se empregava com ele o raciocínio", necessitando, “como diz Sófocles, 'vários freios e vários lemes ao mesmo tempo', mandou vir o mais sábio e ilustre dos filósofos, Aristóteles, a quem proporcionou honorários magníficos e dignos do grande homem". Alexandre com ele "aprendeu não apenas ética e política, mas teve também acesso às lições secretas e mais profundas que os filósofos designam com a terminologia especial de acroamáticas e epópticas, que jamais divulgam" (Vidas paralelas, 
Alexandre 7). O mesmo Plutarco julga que Alexandre tinha "uma vocação inata para a leitura e literatura", considerando "a Ilíada um viático para o valor guerreiro e assim a chamava: levava sempre consigo a edição que Aristóteles preparara desse poema, a chamada 'edição do estojo', mantendo-a sob o travesseiro, ao lado da espada, segundo conta Onesícrito" (Vidas paralelas, Alexandre 8).

$\mathrm{Na}$ obra do Pseudo-Calístenes, a relação de Alexandre com Aristóteles parece ter como escopo a exaltação da inteligência ímpar do discípulo mais que os ensinamentos do filósofo. Perguntando Aristóteles, certa vez, a seus discípulos o seguinte: "Se você herdasse do seu pai o reinado, o que você daria de presente a mim, seu mestre?", e tendo um rapaz respondido que o faria "famoso diante de todos", outro que o faria "intendente e [...] conselheiro de todos os meus julgamentos", Alexandre retrucou: "Agora você pode perguntar sobre as coisas futuras, não tendo segurança sobre as coisas do amanhã? Responderei a você quando chegar o tempo e a hora. Aristóteles respondeu a ele: - Viva, Alexandre, senhor do universo! Você será um grande rei!” (Pseudo-Calístenes 16).

Essa relação perdura durante toda a vida de Alexandre, algumas das partes etnográficas e, por assim dizer, científicas do romance sendo constituídas por cartas dele à mãe e ao antigo mestre. ${ }^{12}$ Sem dúvida essa convivência com o filósofo por excelência faz

${ }^{12} \mathrm{O}$ tópico da amizade entre Alexandre e Aristóteles conheceu uma notável expansão, como no exemplo de Aristóteles cavalgado, cujo primeiro registro remonta aos Sermões quotidianos e comuns de Jacques de Vitry (séc. XIII), traduzido em português provavelmente no século XIV e incluído no Horto do esposo, cuja versão apresento no português medieval (trata-se de um exemplum em sentido estrito, com uma finalidade moralizante, em que, ao sabor da misoginia medieval, está em causa o perigo representado pelas mulheres, a astúcia feminina e o triunfo da sabedoria de Aristóteles): "Arisotelles, o grãde philosoffo, ẽsinava e castiguava rey Alexandre que se nõ ajuntasse ameude a sua molher. E Alexandre fazia asy como lhe cõselhava Aristotiles e sua molher ouve desto grãde pesar e trabalhou-sse de saber porque fazia esto rey Alexandre. E soube por certo que seu mestre Aristotiles procurara esto e penssou muyto como sse vinganria de Aristotiles e entẽdeo que se vingaria per esta gisa: começou de sse trabalhar que fezesse que ele sse movesse a cõsintyr ẽ maa cobiiça della e pera esto começou o oolhar cõ rostro prazivel e fazia-lhe geestos e sinaaes per que ele ẽtendesse que ela se pagava delle. E hia-sse a huũ orto e oolhavo-o per hũa freesta de hũa camara em que ele estudava que saya a aquele orto e aas vezes andava perante ele descalça cõ as pernas descobertas, mostrandolhe per sinaes e per geestos que o amava. E e tãto fez estas cousas perante ele que converteo o seu coraçõ emno seu amor e ẽ cobiiça de fazer maldade cõ ela, per tal gisa que ele a rogou que cõsintysse aa voontade dele. E ella lhe rrespõdeo dizendo: Creo que tu me queres provar e ẽganar, ca nõ posso creer per nehũa maneyra que homem tã sabedor e tã ssesudo, como tu es, quisesse fazer taaes cousas. E elle persseverava ẽna demandar e a raynha lhe disse: Per esta gisa saberey que tu me amas de todo coraçom se quiseres fazer por meu amor aquelo que te eu diseer. E ele lhe prometeo que fazia toda cousa que lhe ela mãdasse e a reynha lhe disse: De manhaa bem cedo, emquanto meu senhor el-rey dormyr, sayrás tu a este orto e poer-te-as curvo ẽ pees e ẽ maaos, ẽ gisa que eu possa cavalgar e andar ẽ cima de ty e ẽtom farey todo teu talente. E ele, porque era preso ẽno amor dela ẽ que cayra pella vista dos olhos per que foy preso ẽ maa cobiiça, pormeteo-lhe que faria todo o que lhe ela dizia. E depois que ella ouve o promitymẽto delle, disse a el-rey Alexãdre: Cras pella manhaa, estade prestes 
de Alexandre não só apto, como curioso em relação às sabedorias existentes nas terras que conquista. É emblemático, dentre outros, seu encontro com os sábios da Índia, “os brâmanes ou oxidorces [...], gimnossofistas que moravam em cabanas e cavernas" completamente nus, os quais, em carta ao rei, declaram ocupar-se "da filosofia", tal qual relatado no Romance de Alexandre. Cito apenas a parte do diálogo relativa a questões cosmológicas:

Alexandre perguntou: - O que é mais forte: a morte ou a vida? Eles responderam: - A vida, porque o sol nascente tem raios brilhantes, mas quando se põe é visto sem força. Ainda perguntou: - O que é maior: a terra ou o mar? Eles responderam: - A terra, porque o próprio mar está coberto de terra por baixo. [...] Perguntou outra vez: - O que nasceu antes: o dia ou a noite? Eles responderam: - A noite, porque os que vão nascer crescem na escuridão da barriga da mãe, então nascem e agarram a luz do dia. Então Alexandre os inquiriu: - Vocês têm um mestre? Eles responderam: - Sim, temos um líder. - Eu gostaria de saudá-lo. Apresentaram-lhe Dandâmis, que estava recostado no chão, sua cama era feita de muitas folhas das árvores e melões maduros, restos de frutas estavam colocados à sua frente. Ao vê-lo, Alexandre saudou-o, e ele disse a Alexandre: - Salve! - mas não se levantou, nem o reverenciou como um rei. Alexandre perguntou a ele quais eram as suas posses. Ele falou: Nossas propriedades são a terra, as árvores frutíferas, a luz, o sol, a lua, a dança das estrelas, a água. [...] Depois de escutar essas coisas, Alexandre disse a todos: - Peçam o que quiserem, que eu darei a vocês! Todos gritaram dizendo: - Nos dê a imortalidade! Alexandre falou: - Esse poder eu não tenho, também sou mortal. Então eles falaram: - Mas então se você é mortal, pelo quê você guerreia? Você conquista tudo, para onde vai levar? Não vão outra vez deixar tudo para outras pessoas? [...] Alexandre levou para Dândamis ouro, pão, vinho e azeite: - Receba isso, ancião, para se lembrar de nós. Dândamis falou, rindo: - Essas coisas nos são inúteis, mas como não queremos menosprezar você, aceitamos o azeite. Então fez uma pilha de lenha e acendeu o fogo, e derramou, na frente de Alexandre, o azeite no fogo. (Pseudo-Calístenes 3, 6)

\footnotetext{
e veredes se devedes creer ao vosso mestre que vos quer arredar e apartar de mỹ. Em outro dia pela manhaa sayo Aristotiles ao orto e a raynha cavalgou sobre elle. E estando ele ẽ pees e ẽ maaos, sobreveo Alexandre que os estava espreytãdo segundo lhe disera a reynha. E el-rey tirou a espada e ameaçou-oho cõ ela que o queria matar e Aristotiles ouve desto muy grãde vergonça e disse a el-rei: Ora podes ẽtender por certo que eu te cõselhava fielmente, porque se a vista e a arte da molher tãto valeo que emganou e catyvou mỹ, que som velho e sabedor, quanto mais poderá ẽganar e fazer dãno a ti, que es mãcebo, se te nõ perceberes tomãdo o exenplo per mỹ. Quãdo el-rey vio que seu mestre lhe respondeo tã saiesmente, amãssou-lhe a sanha e perdoou-lhe. E asy parece quanto dano vẽ ao homẽ per aazo da vista."
} 
A par desse tipo de tradição grega, encontram-se os relatos de origem judaica, no mesmo feitio de encontro de sábios, com várias versões nas tradições rabínicas. Assim, conforme a agadah relativa ao diálogo entre Alexandre e os Sábios do Sul (Ziknei ha'negev), a Gemara relata que o rei lhes propôs dez questões, dentre as quais: a) "Quem é sábio?", ao que eles respondem: "Aquele que prevê o que será"; b) "Quem é poderoso?", com a resposta: "Quem domina sua inclinação para o mal (yetzeer hara); c) "Quem é rico?", ao que os sábios retrucam: "Quem se alegra com sua parte". Além desse tipo de questões de ordem moral, existem as de caráter mais especulativo:

Alexandre Makdon perguntou dez coisas aos sábios do sul. Disse a eles: - Os céus estão mais longe da terra, ou o leste do oeste? Disseram-lhe: - O leste do oeste. Você pode saber: quando o sol está no leste, todo mundo olha-o. Quando o sol está no oeste, todo mundo olha-o. Mas quando o sol está no meio do céu, não podem olhá-lo. Os dois são iguais, como está escrito: "O quanto os céus estão elevados acima da terra... assim o leste é distante do oeste" (Salmo 103, 11-12). Se fossem distâncias diferentes, a Escritura deveria ter descrito a misericórdia dos céus usando a distância maior, de modo que você é forçado a concluir que as distâncias são iguais e que essa é a razão pela qual alguém pode olhar o sol no nascente e no poente é que as colinas e montanhas que estão no caminho do sol o sombreiam. Isso não acontece quando ele está no alto do céu. Embora as distâncias sejam iguais, não há como olhá-lo, pois não há nada bloqueando-o. (Tamid 32 apud Amitay, 2012)

A esse tópico relativo aos contatos de Alexandre com homens sábios cumpre acrescentar a tradição persa medieval de suas relações com Platão, estudada por Casari. No Livro das figuras dos climas (Kitäb suwāar al-aqälim), datado no séc. XIV, o autor afirma que o esboço da quarta parte habitada do globo que apresenta foi encontrado na biblioteca do príncipe, constituindo um comentário de texto encomendado a Platão por Alexandre, quando tinha dezesseis anos, para servir-lhe de guia na conquista do mundo: a obra inclui mapas e informações demográficas, tendo sido transmitida a Alexandre por Aristóteles, enquanto discípulo de Platão, no ano 770 antes da Égira. Em outro texto persa, o Livro de Dario (Däräbnāme), escrito no século XII por Tarsusi, Alexandre gasta a primeira parte de suas aventuras à busca de Platão, o próprio Aristóteles insistindo com ele que "não é possível explorar o mundo sem Platão, porque ele é o único que conhece o que é e não é no mundo" (Casari, 2012, p. 192-3). Do mesmo modo, no poema de Amir Khosrow, O espelho de Alexandre (A'ine-ye Eskandari), de cerca de 1300, é o "divino sábio" (akim-e elähì) Platão quem fornece a Alexandre o plano do veículo submarino o qual lhe possibilita descer às profundezas do Grande Mar, a construção do mesmo ficando a cargo de Aristóteles - uma divisão de tarefas significativa, que define um como projetista (ou teórico), o outro como mecânico (ou prático). Uma miniatura em manuscrito dessa mesma obra mostra uma visita de Alexandre a Platão, o qual se encontra, significativamente, em sua caverna: o tema do 
diálogo entre os dois é a política e a capacidade de liderança. Observe-se que a efabulação dessas relações de Alexandre com Platão tem como consequência fazer de Aristóteles um simples intermediário, encarregado de funções práticas, num certo sentido alguém do mesmo estatuto de Alexandre, enquanto ambos se põem como discípulos de Platão.

Para terminar esse percurso já longo pelos lugares comuns que se somaram na figura de Alexandre e dele, em seguida, decorreram, acrescento apenas o comentário de Alexandre, em Troia, sobre Aquiles, conforme conservado por Plutarco:

No túmulo de Aquiles, depois de untar o corpo com óleo e, segundo o costume, correr nu com seus companheiros, depositou coroas, dizendo: Bem feliz foste tu, Aquiles, pois, vivo, tiveste um amigo fiel e, morto, um grande arauto de tua glória! (Vidas paralelas, Alexandre 15)

Se Alexandre não teve um Homero, deu origem a um verdadeiro mar de histórias que se expandiu mais que a própria Ilíada, em prosa e verso, em muitas línguas e culturas da zona de convergência cultural à qual ele deu um desenho político e uma conformação helenizada, atuando como o elo de transmissão de lugares comuns que para ele confluíram e dele defluíram.

\section{REFERÊNCIAS}

AMITAY, Ori. Alexander in Bavli Tamid: in search for a meaning. In: STONEMAN, Richard et al. (ed.). The Alexander Romance in Persia and East. Groningen: Barkhuis Publishing, 2012, p. 349-365.

BÉROUL. O romance de Tristão. Tradução de Jacyntho Lins Brandão. São Paulo: Editora 34, 2020.

BOMPAIRE, Jacques. Lucien écrivain, imitation et création. Paris: Les Belles Lettres; Torino: Nino Aragno, 2000.

CALÍSTENES, Pseudo-. Vida e feitos de Alexandre da Macedônia. Tradução de Laura Cohen Rabelo. In: RABELO, Laura Cohen. Vida e feitos de Alexandre da Macedônia: tradução e comentário de um romance de Alexandre grego. Dissertação (Mestrado em Estudos Literários) - Programa de Pós-graduação em Estudos Literários da Faculdade de Letras, Universidade Federal de Minas Gerais, Belo Horizonte, 2017.

CASARI, Mario. The king explorer: a cosmographic approach to the Persian Alexander. In: STONEMAN, Richard et al. (ed.). The Alexander Romance in Persia and East. Groningen: Barkhuis Publishing, 2012, p. 175-204.

DALLEY, Stephanie. Myths from Mesopotamia. Creation, the Flood, Gilgamesh, and others. Oxford: University Press, 2008. 
DOUFIKAR-AERTS, Faustina C. W. King Midas' ears on Alexander's head: in search of the Afro-Asiatic Alexander cycle. In: STONEMAN, Richard et al. (ed.). The Alexander Romance in Persia and East. Groningen: Barkhuis Publishing, 2012, p. 61-80.

ENNIUS. The tragedies of Ennius. Ed. H. D. Jocelyn. Cambridge: University Press, 1967.

FULINSKA, Agnieszka. Oriental imagery and Alexander's legend in art: reconnaissance. In: STONEMAN, Richard et al. (ed.). The Alexander Romance in Persia and East. Groningen: Barkhuis Publishing, 2012, p. 383-404.

GEIER, Robert. Alexandri M. historiarum scriptores aetate suppares. Leipzig: Libraria Gebaueria, 1844.

GEORGE, Andrew R. The Babylonian Gilgamesh Epic. Introduction, critical edition and cuneiform texts. Oxford: Oxford University Press, 2003.

GRIMALDI, William M. A. Aristotle, Rhetoric I: A commentary. New York: Fordham University Press, 1980.

KADARÉ, Ismail. A filha de Agamenon \& O sucessor. Tradução de Bernardo Joffily. São Paulo: Cia. das Letras, 2006.

LAUSBERG, Heinrich. Elementos de retórica literária. Tradução, prefácio e aditamentos de R. M. Rosado Fernandes. Lisboa: Calouste Gulbenkian, 1993.

MANTEGHI, Haila. Alexander the Great in the Shähnämeh of Ferdowsī. In: STONEMAN, Richard et al. (ed.). The Alexander Romance in Persia and East. Groningen: Barkhuis Publishing, 2012, p. 161-174.

MODENA, Martina. Horto do esposo: edizione critica elettronica. Tese (Doutorado em Italianística e Filologia Clássico-Medieval). Scuola Dottorale di Ateneo, Università Ca'Foscari, Venezia, 2016. Disponível em: http://dspace.unive.it/bitstream/handle/10579/8277/825511-1166803. pdf? sequence $=2$.

OVÍDIO. Metamorfoses. Edição bilíngue. Tradução, introdução e notas de Domingos Lucas Dias. Apresentação João Angelo Oliva Neto. São Paulo: Ed. 34, 2017.

PLUTARCO. Vidas paralelas. Introdução e notas de Paulo Matos Peixoto. Trad. Gilson César Cardoso. São Paulo: Paumape, 1992.

PLUTARQUE. Vies. Edição e tradução de Robert Flacelière, Émile Chambry e Marcel Juneaux. Paris: Les Belles Lettres, 1966.

QUET, Marie-Henriette. Rhétorique, culture et politique: le fonctionnement du discours idéologique chez Dion de Pruse et dans les Moralia de Plutarque. Dialogues d'bistoire ancienne, v. 4, p. 51-118, 1978.

SCHMIDT, Victor M. A legend and its image: the aerial flight of Alexander the Great in Medieval art. Translated by Xandra Bardet. Groningen: Egbert Forsten, 1995. 
SELDEN, Daniel L. Mapping the Alexander Romance. In: STONEMAN, Richard et al. (ed.). The Alexander Romance in Persia and East. Groningen: Barkhuis Publishing, 2012, p. 19-60. STONEMAN, Richard; ERICKSON, Kyle; NETTON, Ian (ed.). The Alexander Romance in Persia and East. Groningen: Barkhuis Publishing, 2012.

WOOD, Michael. In the Footsteps of Alexander the Great: A Journey from Greece to Asia. Berkeley: University of California Press, 1997.

ZUWIYYA, Z. Daniel. The Alexander Romance in the Arabic tradition. In: (ed.). $A$ companion to Alexander literature in the Middle Ages. Leiden: Brill, 2011, p. 73-112. 
